\title{
Analysis of the impact of Information Disclosure Violation on audit opinions and audit fees of listed companies
}

\author{
Ya Liu ${ }^{1.2}$, Zhao Yuanyi ${ }^{1}$ and Wang Jue ${ }^{1}$ \\ ${ }^{1}$ Business School, Sichuan Normal University \\ ${ }^{2}$ Business School, Sichuan University
}

Keywords: Information Disclosure, Violation, Audit opinion, Audit fees

\begin{abstract}
In the first half of 2018, there were 63 cases of information disclosure violations in listed companies, accounting for nearly $40 \%$ of the administrative penalties imposed by the SFC. This paper takes information disclosure violations as a starting point to investigate the impact of corporate information disclosure violations on audit opinions and audit fees. We choose the data of manufacturing listed companies from 2012 to 2017 for regression analysis, and the results show that there is a significant positive correlation between information disclosure violation and non-standard audit opinions issued in the same year, audit fees in the same year and subsequent years. The results show that audit verification of accounting firms can identify violations of corporate information disclosure, and make appropriate "response" through audit opinions and audit fees.
\end{abstract}

\section{Introduction}

The Information Disclosure of the Listed Firm is in chaos, such as delaying information disclosure, wrong information disclosure. It not only causes the loss to the stakeholders in the securities trading, but also decreases the credibility of the relevant information disclosure institution.

For auditors, if they fail to conduct auditing strictly with the application of the relevant laws, not only will they suffer the pressure from the social public, but also take serious legal liabilities. Therefore, whether the violation of information disclosure will affect the audit opinions issued and what changes will be made to the relevant audit fees, are worth of our detailed investigation.

\section{Definition and types of information disclosure violation of listed companies}

Information disclosure refers to the act of listed company to release its assets and operating results in a specific time and method through specified media intermediary (Jianbin Xu, 2016). Information disclosure violations refer to the listed companies violate laws and regulations by failing to make due disclosure at the specified time and place with specified requirements.

Therefore, information disclosure violation of listed companies is generally divided into two categories, "false statements" and "delayed disclosure". The information disclosure violations includes dishonest information disclosure, incomplete information disclosure, delayed information disclosure and non-standard information disclosure.

\section{Empirical Analysis Design}

\subsection{Research hypothesis}

According to some relevant researches, audit opinions have obvious value relevance. The response of the market to non-standard audit opinions is stronger compared to the response of the market standard audit opinions, so the type of audit opinions is considerable for report users (Yuangang Duan, Bo Chen, 2017). Therefore, this paper proposes:

H1: when it comes to information disclosure violations of listed companies, there is a higher probability of the proposition of non-standard audit opinions increased that year.

From the perspective of audit work, auditors usually need to charge higher audit fees to compensate for the loss caused by the audit failure or execute additional audit procedures to reduce 
the audit risk. An additional audit procedure will increase the audit cost. As a result, this paper proposes that:

H2-1: when it comes to the information disclosure violations of listed companies, the audit fees charged by accounting firms in that year are higher.

In the following year of information disclosure in violation, the auditor may continuously focus on previous violations of the auditing units, arguing that there are potential risks for audited financial statements, further substantive tests will be taken to determine risks, increasing the audit fees. Therefore, this paper proposes:

$\mathrm{H} 2-2$ : when it comes to the information disclosure violations of listed companies, the audit fees charged by accounting firms are higher in the next year.

\subsection{Sample selection and data sources}

The standards of auditing fees vary greatly among various industries. Industry type of manufacturing industry was chosen for facilitate comparison and observation samples of listed manufacturing companies from 2013 to 2016 are selected. However, the actual sample data from 2012 to 2017 are used because the previous audit opinion and the audit fees in the next year respectively need the data of the previous year and the next year. Finally, the listed companies with negative total assets or net assets and the listed companies with missing or abnormal relevant data are eliminated, as shown in table 1.

Table 1 General samples situation

\begin{tabular}{c|c|c|c|c|c}
\hline Year & \multicolumn{2}{|c|}{ Violation samples } & \multicolumn{2}{c|}{ Non-violation samples } & Total \\
\hline 2013 & 81 & $6.66 \%$ & 1136 & $93.34 \%$ & 1217 \\
\hline 2014 & 57 & $4.13 \%$ & 1322 & $95.87 \%$ & 1379 \\
\hline 2015 & 90 & $7.09 \%$ & 1179 & $92.91 \%$ & 1269 \\
\hline 2016 & 84 & $5.83 \%$ & 1358 & $94.17 \%$ & 1442 \\
\hline Total & 312 & $5.88 \%$ & 4995 & $94.12 \%$ & 5307 \\
\hline
\end{tabular}

\subsection{Variable definition and model construction}

\subsubsection{Variable definition}

Table 2 Variable definition

\begin{tabular}{|c|c|c|c|c|}
\hline \multicolumn{2}{|c|}{ Types } & Name of variable & Symbol & Variable calculation \\
\hline \multicolumn{2}{|c|}{ Explanatory variables } & $\begin{array}{l}\text { Violate information } \\
\text { disclosure or not }\end{array}$ & Punish & $\begin{array}{c}1 \text { represents for yes, } 0 \text { represents for } \\
\text { no }\end{array}$ \\
\hline \multirow{3}{*}{\multicolumn{2}{|c|}{ Explained variable }} & Audit opinions & Opinion & $\begin{array}{c}\text { Standard audit opinion is set to } 0, \\
\text { while others are set to } 1\end{array}$ \\
\hline & & $\begin{array}{c}\text { Audit fees natural } \\
\text { logarithm in the year }\end{array}$ & InFee & $\begin{array}{c}\text { Audit fees natural logarithm in the } \\
\text { year }\end{array}$ \\
\hline & & $\begin{array}{l}\text { Audit fees natural } \\
\text { logarithm in next year }\end{array}$ & InNextFee & $\begin{array}{c}\text { Audit fees natural logarithm in next } \\
\text { year }\end{array}$ \\
\hline \multirow{9}{*}{$\begin{array}{l}\text { Control } \\
\text { variables }\end{array}$} & \multirow{3}{*}{$\begin{array}{l}\text { Business } \\
\text { complexity }\end{array}$} & The company size & Size & The natural logarithm of total assets \\
\hline & & $\begin{array}{l}\text { The proportion of accounts } \\
\text { receivable in total assets }\end{array}$ & Arr & Account receivables/Total assets \\
\hline & & $\begin{array}{c}\text { The proportion of } \\
\text { inventory in total assets }\end{array}$ & Invr & Inventory/Total assets \\
\hline & \multirow{2}{*}{$\begin{array}{l}\text { Financial } \\
\text { risk }\end{array}$} & Asset-liability ratio & Lev & Liability/Total assets \\
\hline & & Current ratio & Cur & Current assets/Current liability \\
\hline & Profitability & Return on net assets & Roe & Earnings after tax/Net assets \\
\hline & \multirow{2}{*}{$\begin{array}{l}\text { Accounting } \\
\text { firm factors }\end{array}$} & Last audit opinion & Last Opinion & $\begin{array}{l}\text { The audit opinion of last period } \\
\text { standard is } 0 \text {, and the other is } 1\end{array}$ \\
\hline & & If it's "Big4" & Big4 & "The Big4"is 1 , and the other is 0 \\
\hline & Others & Loss or not & Loss & Loss is 0 , and the other is 1 \\
\hline
\end{tabular}




\subsubsection{Model construction of audit opinions}

Opinion $=\beta_{0}+\beta_{1}$ Punish $+\beta_{2}$ Size $+\beta_{3}$ Roe $+\beta_{4}$ Lev $+\beta_{5}$ Loss $+\beta_{6}$ Big $4+\beta_{7}$ Arr $+\beta_{8}$ Invr $+\beta_{9}$ Cur $+\beta_{10}$ LastOpinion $+\varepsilon$

3.3.3 Model construction of audit fees Empirical results and analysis

InFee $=\beta_{0}+\beta_{1}$ Punish $+\beta_{2}$ Size $+\beta_{3}$ Roe $+\beta_{4}$ Lev $+\beta_{5}$ Loss $+\beta_{6}$ Big $4+\beta_{7}$ Arr $+\beta_{8}$ Invr $+\beta_{9}$ Cur $+\beta_{10}$ LastOpinion $+\varepsilon$ (2-1 )

InNextFee $=\beta_{0}+\beta_{1}$ Punish $+\beta_{2}$ Size $+\beta_{3}$ Roe $+\beta_{4}$ Lev $+\beta_{5}$ Loss $+\beta_{6}$ Big $4+\beta_{7}$ Arr $+\beta_{8}$ Invr $+\beta_{9}$ Cur $+\beta_{10}$ LastOpinion $+\varepsilon$ (2-2)

\section{Empirical results and analysis}

\subsection{Descriptive statistics}

As it was shown in table 3, a general descriptive analysis of the sample is taken first. The mean of Punish is 0.0588 which indicates the proportion of samples with violations is $5.88 \%$. The mean of the Opinion is 0.0239 , which indicates the probability of non-standard audit opinions issued by the listed company is only $2.39 \%$. According to the minimum, maximum and mean values of Size, Arr, Invr, Lev, Cur and Roe, the corresponding financial indicators of each sample are significantly different due to the company's asset size and operating conditions. The mean values of Loss and Big4 are 0.9533 and 0.0456 respectively, indicating that $95.33 \%$ of listed companies have no loss in the overall sample, and $4.56 \%$ of the audit reports of listed companies were issued by "Big 4 accounting firms".

Secondly, based on the occurrence of the violation, these samples were divided into two groups for descriptive analysis, and shown in table 4 . The mean of Opinion is $9.04 \%$, and there is a significant gap between the variables of the two samples. By inference the violation group of information disclosure of listed companies is more likely to be issued non-standard audit opinion in that year than the non-violation group. According to the difference between the mean values of InFee and InNextFee, the audit fees of the violation group are slightly higher than the non-violation group. A preliminary judgment of audit fees can be made---they are higher in the violation group of information disclosure of listed companies than in the non-violation group. There is no significant difference among the other control variables except the current ratio (Cur) violation group is observably lower than the non-violation group, which indicates that the company takes higher financial risks under information disclosure violations.

Table 3 Descriptive statistics of the sample population

\begin{tabular}{c|c|c|c|c|c}
\hline & $\mathrm{N}$ & The minimum & The maximum & The mean & The standard deviation \\
\hline Punish & 5307 & 0.00 & 1.00 & 0.0588 & 0.23525 \\
\hline Opinion & 5307 & 0.00 & 1.00 & 0.0239 & 0.15285 \\
\hline InFee & 5307 & 11.92 & 17.20 & 13.6738 & 0.63951 \\
\hline InNextFee & 5307 & 12.21 & 17.31 & 13.7711 & 0.63934 \\
\hline Size & 5307 & 17.76 & 26.96 & 22.0036 & 1.11993 \\
\hline Arr & 5307 & 0.00 & 0.70 & 0.1308 & 0.09653 \\
\hline Invr & 5307 & 0.00 & 0.86 & 0.1393 & 0.08997 \\
\hline Lev & 5307 & 0.03 & 1.00 & 0.3983 & 0.19390 \\
\hline Cur & 5307 & 0.09 & 38.25 & 2.4986 & 2.53882 \\
\hline Roe & 5307 & -0.80 & 0.87 & 0.0731 & 0.09514 \\
\hline LastOpinion & 5307 & 0.00 & 1.00 & 0.0224 & 0.14807 \\
\hline Loss & 5307 & 0.00 & 1.00 & 0.9533 & 0.21108 \\
\hline Big4 & 5307 & 0.00 & 1.00 & 0.0456 & 0.20864 \\
\hline
\end{tabular}


Table 4 Descriptive statistics of sample groups

\begin{tabular}{c|c|c|c|c|c|c|c}
\hline & $\mathrm{N}$ & The mean & $\begin{array}{c}\text { The } \\
\text { standard } \\
\text { deviation }\end{array}$ & $\mathrm{N}$ & The mean & $\begin{array}{c}\text { The standard } \\
\text { deviation }\end{array}$ & $\begin{array}{c}\text { The mean } \\
\text { difference }\end{array}$ \\
\hline & Effective & & & Effective & & & \\
\hline Opinion & 312 & 0.1090 & 0.31211 & 4995 & 0.0186 & 0.13519 & 0.0904 \\
\hline InFee & 312 & 13.7228 & 0.59963 & 4995 & 13.6707 & 0.64185 & 0.0521 \\
\hline InNextFee & 312 & 13.8270 & 0.55820 & 4995 & 13.7676 & 0.64395 & 0.0594 \\
\hline Size & 312 & 21.9434 & 1.13373 & 4995 & 22.0073 & 1.11907 & -0.0639 \\
\hline Arr & 312 & 0.1322 & 0.10239 & 4995 & 0.1307 & 0.09616 & 0.0015 \\
\hline Invr & 312 & 0.1371 & 0.09321 & 4995 & 0.1394 & 0.08978 & -0.0023 \\
\hline Lev & 312 & 0.4677 & 0.19631 & 4995 & 0.3940 & 0.19294 & 0.0737 \\
\hline Cur & 312 & 1.8321 & 1.39255 & 4995 & 2.5403 & 2.58806 & -0.7082 \\
\hline Roe & 312 & 0.0567 & 0.12371 & 4995 & 0.0741 & 0.09298 & -0.0174 \\
\hline LastOpinion & 312 & 0.0833 & 0.27683 & 4995 & 0.0186 & 0.13519 & 0.0647 \\
\hline Loss & 312 & 0.9423 & 0.23354 & 4995 & 0.9540 & 0.20961 & -0.0117 \\
\hline Big4 & 312 & 0.0321 & 0.17642 & 4995 & 0.0464 & 0.21047 & -0.0143 \\
\hline
\end{tabular}

\subsection{Correlation analysis}

The correlation coefficient is listed in table 5. According to the data analysis, there is a significant correlation between the violation of information disclosure and the audit opinions published at the 1\% level, but there is no significant correlation between audit fees in current and the next year. As a result, it needs to be verified by regression analysis. In addition, the correlation coefficient between the independent variable and the control variable is mostly less than 0.1 but the maximum is only 0.633 , indicating that there is no multicollinearity problem and it does not affect the following regression analysis results.

Table 5 Pearson correlation coefficient of variables

\begin{tabular}{|c|c|c|c|c|c|c|c|}
\hline & Punish & Opinion & InFee & InNextFee & Size & Arr & Invr \\
\hline Punish & 1 & & & & & & \\
\hline Opinion & $0.139 * * * 1$ & 1 & & & & & \\
\hline InFee & 0.019 & $0.039 * * *$ & 1 & & & & \\
\hline InNextFee & 0.022 & 0.021 & $0.930 * * *$ & 1 & & & \\
\hline Size & -0.013 & $-0.031 * *$ & $0.758^{* * *}$ & $0.730 * * *$ & 1 & & \\
\hline Arr & 0.004 & $-0.053 * * *$ & $-0.103^{* * *}$ & $-0.087 * * *$ & $-0.126^{* * *}$ & 1 & \\
\hline Invr & -0.006 & 0.004 & 0.020 & 0.012 & 0.007 & -0.006 & 1 \\
\hline Lev & $0.089 * * *$ & $0.161^{* * *}$ & $0.393 * * *$ & $0.378 * * *$ & $0.505^{* * *}$ & $0.072 * * *$ & $0.169^{* * *}$ \\
\hline Cur & $-0.066^{* * *}$ & $-0.072 * * *$ & $-0.280 * * *$ & $-0.275^{* * *}$ & $-0.320 * * *$ & $-0.048 * * *$ & $-0.099 * * *$ \\
\hline Roe & $-0.043 * * *$ & $-0.133 * * *$ & $0.048^{* * *}$ & $0.069 * * *$ & $0.077 * * *$ & $0.057 * * *$ & $-0.044 * * *$ \\
\hline LastOpinion & $0.103 * * *$ & $0.526^{* * *}$ & $0.024^{*}$ & 0.008 & $-0.031 * *$ & $-0.048 * * *$ & 0.003 \\
\hline Loss & -0.013 & $-0.158 * * *$ & $-0.052 * * *$ & $-0.032 * *$ & -0.005 & $0.046^{* * *}$ & 0.001 \\
\hline Big4 & -0.016 & -0.022 & $0.433 * * *$ & $0.413 * *$ & $0.340 * * *$ & $-0.052 * *$ & $-0.026^{*}$ \\
\hline
\end{tabular}

Pre-continuation table

\begin{tabular}{c|c|c|c|c|c|c}
\hline & Lev & Cur & Roe & LastOpinion & Loss & Big4 \\
\hline Punish & & & & & & \\
\hline Opinion & & & & & & \\
\hline
\end{tabular}

$1 *, * *$ and $* * *$ mean significant at the level of $10 \%, 5 \%$ and $1 \%$ respectively, 


\begin{tabular}{c|c|c|c|c|c|c}
\hline InFee & & & & & & \\
\hline InNextFee & & & & & & \\
\hline Size & & & & & & \\
\hline Arr & & & & & & \\
\hline Invr & & & & & & \\
\hline Lev & 1 & & & & & \\
\hline Cur & $-0.633 * * *$ & 1 & & & & \\
\hline Roe & $-0.150 * * *$ & $0.083 * * *$ & 1 & & & \\
\hline LastOpinion & $0.145^{* * *}$ & $-0.062^{* * *}$ & $-0.054 * * *$ & 1 & & \\
\hline Loss & $-0.167 * * *$ & $0.086 * *$ & $0.556 * * *$ & $-0.099 * * *$ & 1 & \\
\hline Big4 & $0.114 * * *$ & $-0.072 * * *$ & $0.091 * * *$ & -0.021 & 0.018 & \\
\hline
\end{tabular}

\subsection{Regression analysis}

\subsubsection{Regression analysis of audit opinion model}

Multivariate regression is used to analyze model-opinion, and the specific results are shown in table 6 and 7. In this model, the adjusted $\mathrm{R}$ square is $0.305, \mathrm{~F}$ is 233.466 , and Sig is 0.000 which is less than 0.01 , indicating that this model is significant and credible.

The Beta coefficient is adopted to represent the relationship between independent variables and dependent variables. The standard B value of the non-standard audit variable is 0.076 and the Sig is 0.000 , indicating that there is a significant positive correlation between the violation of information disclosure and the non-standard audit opinion issued in that year, thereby verifying H1: when it comes to information disclosure violations of listed companies, there is a higher probability for the auditor to issue non-standard audit opinion in that year.

Furthermore, the audit opinion was significantly negative related Size, the proportion of Arr, Roe and Loss at the 1\% level, while it was significantly positive related to Lev and LastOpinion at the 1\% level, but there was no significant correlation with other control variables. Audit opinions that year were proposed with more considerations of the company's financial operation status and audit opinions of the previous period. However, in recent years, the correlation between audit opinion and Big4 variable is barely noticeable, because the audit opinion issued is fairer and more objective.

Table 6 Significance analysis of audit opinion model

\begin{tabular}{c|c|c|c|c|c}
\hline & Sum of squares & $\mathrm{df}$ & Mean square & $\mathrm{F}$ & Sig \\
\hline Regression & 37.927 & 10 & 3.793 & 233.466 & $0.000^{* * * 2}$ \\
\hline Residual & 86.034 & 5296 & 0.016 & & \\
\hline Total & 123.961 & 5306 & & & \\
\hline
\end{tabular}

$*, * *$ and $* * *$ mean significant at the level of $10 \%, 5 \%$ and $1 \%$ respectively, the same as below.

Table 7 Analysis of audit opinion model coefficients

\begin{tabular}{|c|c|c|c|c|c|c|}
\hline & \multirow{2}{*}{$\mathrm{N}$} & \multicolumn{2}{|c|}{ Non-standardized coefficient } & \multirow{2}{*}{ Beta } & \multirow{2}{*}{$\mathrm{T}$} & \multirow{2}{*}{ Sig } \\
\hline & & $\mathrm{B}$ & The standard error & & & \\
\hline (Constant) & 5307 & 0.246 & 0.044 & & 5.652 & $0.000 * * *$ \\
\hline Punish & 5307 & 0.049 & 0.008 & 0.076 & 6.547 & $0.000 * * *$ \\
\hline Size & 5307 & -0.010 & 0.002 & -0.072 & -4.921 & $0.000 * * *$ \\
\hline Arr & 5307 & -0.064 & 0.019 & -0.040 & -3.413 & $0.001 * * *$ \\
\hline Invr & 5307 & -0.029 & 0.020 & -0.017 & -1.453 & 0.146 \\
\hline Lev & 5307 & 0.097 & 0.014 & 0.123 & 7.072 & $0.000 * * *$ \\
\hline Cur & 5307 & 0.001 & 0.001 & 0.024 & 1.589 & 0.112 \\
\hline Roe & 5307 & -0.072 & 0.023 & -0.045 & -3.174 & $0.002 * * *$ \\
\hline LastOpinion & 5307 & 0.505 & 0.012 & 0.489 & 41.486 & $0.000 * * *$ \\
\hline Loss & 5307 & -0.046 & 0.010 & -0.064 & -4.595 & $0.000 * * *$ \\
\hline Big4 & 5307 & 0.003 & 0.009 & 0.004 & 0.333 & 0.739 \\
\hline Adjusted R square & \multicolumn{6}{|c|}{0.305} \\
\hline
\end{tabular}




\subsubsection{Regression analysis of audit fees model}

a) Regression analysis of audit fees model in that year

Model-InFee uses multiple regression analysis. The adjusted $\mathrm{R}$ square is 0.616 , while $\mathrm{F}$ is 852.964 , and Sig is 0.000 which is much lower than 0.01, indicating the high degree of fitting of the model.

As it was shown in table 9, the regression results of the model results from the coefficient analysis. The standard coefficient of variable information disclosure is 3.071 and the Sig is 0.002 , indicating that there is a significant positive correlation between the violation of information disclosure and the audit fees charged in that year at the $1 \%$ level, thereby verifying $\mathrm{H} 2-1$ : when there are information disclosure violations of listed companies, the audit fees charged by the accounting firm in that year are higher.

In addition, audit fees in that year have a positive correlation with Size and LastOpinion at the 1\% level, and the proportion of Invr at the 5\% level. The audit fees were significantly negatively correlated with Cur at 1\% level and positively correlated with Lev at 5\% level. It indicates that the more complicated the business status of listed companies are, the higher financial risks and the audit fees charged by accounting firms are. The audit fees are significantly negatively related to variable Loss at $1 \%$ level, since the lower business level of loss-making companies together with weaker continuous operation ability will result in a higher probability to commit irregularities and frauds to whitewash the actual situation of the company. The auditor will charge higher audit fees as they need to pay more attention to such companies. The audit fees are significantly positively correlated with the variable Big4 at the 1\% level, because auditors who are in Big4 have excellent business skills and reputation costs, which caused higher fees charged by the Big4 auditors.

Table 8 Significance analysis of audit fees models of that year

\begin{tabular}{c|c|c|c|c|c}
\hline & Sum of squares & df & Mean square & F & Sig \\
\hline Regression & 1338.773 & 10 & 133.877 & 852.964 & $0.000 * * *$ \\
\hline Residual & 831.236 & 5296 & 0.157 & & \\
\hline Total & 2170.008 & 5306 & & & \\
\hline
\end{tabular}

Table 9 audit fee models coefficient analysis of that year

\begin{tabular}{|c|c|c|c|c|c|c|}
\hline \multirow{2}{*}{ Model } & \multirow{2}{*}{$\mathrm{N}$} & \multicolumn{2}{|c|}{ Non-standardized coefficient } & \multirow{2}{*}{$\begin{array}{c}\text { The standard } \\
\text { coefficient }\end{array}$} & \multirow{2}{*}{$\mathrm{T}$} & \multirow{2}{*}{ Sig } \\
\hline & & B & Standard error of & & & \\
\hline (Constant) & 5307 & 5.201 & 0.135 & & 38.397 & $0.000 * * *$ \\
\hline Punish & 5307 & 0.072 & 0.023 & 0.026 & 3.071 & $0.002 * * *$ \\
\hline Size & 5307 & 0.393 & 0.006 & 0.688 & 63.087 & $0.000 * * *$ \\
\hline Arr & 5307 & -0.017 & 0.058 & -0.003 & -0.291 & 0.771 \\
\hline Invr & 5307 & 0.144 & 0.062 & 0.020 & 2.338 & $0.019 * *$ \\
\hline Lev & 5307 & -0.105 & 0.043 & -0.032 & -2.473 & $0.013 * *$ \\
\hline Cur & 5307 & -0.014 & 0.003 & -0.056 & -5.067 & $0.000 * * *$ \\
\hline Roe & 5307 & 0.083 & 0.070 & 0.012 & 1.186 & 0.236 \\
\hline LastOpinion & 5307 & 0.185 & 0.038 & 0.043 & 4.881 & $0.000 * * *$ \\
\hline Loss & 5307 & -0.166 & 0.031 & -0.055 & -5.308 & $0.000 * * *$ \\
\hline Big4 & 5307 & 0.613 & 0.028 & 0.200 & 22.016 & $0.000 * * *$ \\
\hline $\begin{array}{l}\text { Adjusted R } \\
\text { square }\end{array}$ & & & & 616 & & \\
\hline
\end{tabular}

b) Regression analysis of audit fee models in the next year

Model-InNextFee adopts the regression analysis method of multiple regression. The adjusted $\mathrm{R}$ square is $0.569, \mathrm{~F}$ is 701.551, and Sig is much lower than 0.01, indicating that this model is significant and credible. As it was shown in table 11, the regression results of the model were 
analyzed. The standard coefficient of variable information disclosure is 0.030 , and the Sig is 0.000 . The audit fees in the next year significantly positively correlated with the occurrence of the information disclosure at the $1 \%$ level, so as to verify $\mathrm{H} 2-2$ : when there are information disclosure violations of listed companies, higher audit fees were charged by accounting firms in the next year.

Table 10 Significance analysis of audit fees models in the next year

\begin{tabular}{c|c|c|c|c|c}
\hline & Sum of squares & $\mathrm{df}$ & Mean square & $\mathrm{F}$ & Sig \\
\hline Regression & 1235.871 & 10 & 123.587 & 701.551 & $0.000 * * *$ \\
\hline Residual & 932.957 & 5296 & 0.176 & & \\
\hline Total & 2168.828 & 5306 & & & \\
\hline
\end{tabular}

Table 11 Audit fees models coefficient analysis in the next year

\begin{tabular}{|c|c|c|c|c|c|c|}
\hline \multirow{2}{*}{ Model } & \multirow{2}{*}{$\mathrm{N}$} & \multicolumn{2}{|c|}{ Non-standardized coefficient } & \multirow{2}{*}{$\begin{array}{c}\text { The standard coefficient } \\
\text { Beta }\end{array}$} & \multirow{2}{*}{$\mathrm{T}$} & \multirow{2}{*}{ Sig } \\
\hline & & $\mathrm{B}$ & Standard error & & & \\
\hline (Constant) & 5307 & 5.630 & 0.144 & & 39.232 & 0.000 \\
\hline Punish & 5307 & 0.082 & 0.025 & 0.030 & 3.310 & 0.001 \\
\hline Size & 5307 & 0.376 & 0.007 & 0.659 & 57.043 & 0.000 \\
\hline Arr & 5307 & 0.041 & 0.062 & 0.006 & .658 & 0.510 \\
\hline Invr & 5307 & 0.084 & 0.065 & 0.012 & 1.287 & 0.198 \\
\hline Lev & 5307 & -0.088 & 0.045 & -0.027 & -1.952 & 0.051 \\
\hline Cur & 5307 & -0.015 & 0.003 & -0.061 & -5.242 & 0.000 \\
\hline Roe & 5307 & 0.213 & 0.074 & 0.032 & 2.860 & 0.004 \\
\hline LastOpinion & 5307 & 0.116 & 0.040 & 0.027 & 2.888 & 0.004 \\
\hline Loss & 5307 & -0.142 & 0.033 & -0.047 & -4.284 & 0.000 \\
\hline Big4 & 5307 & 0.574 & 0.030 & 0.187 & 19.472 & 0.000 \\
\hline $\begin{array}{l}\text { Adjusted R } \\
\text { square }\end{array}$ & \multicolumn{6}{|c|}{0.569} \\
\hline
\end{tabular}

c) Comparative analysis

Based on the regression analysis coefficient of above models, the significant value of audit fees in the year of listed company information disclosure violations and the next year are 0.002 and 0.001 respectively, both of them reflect a positive relationship at the $1 \%$ level. The influence of the information disclosure violations of that year to audit fees was more significantly than the next year, but the difference was not considerable. Although it would be decreased sightly, it will cause a huge influence as the inherent occupational rigor owned by auditors. In conclusion, there is a significant impact on audit fees in the year of information disclosure violation of listed companies and the subsequent years, which is also positively correlated.

\section{Research conclusions and countermeasures}

\subsection{Research conclusions}

There is a significant positive correlation between information disclosure violation of listed companies and non-standard audit opinion issued by auditors. As a company with illegal behaviors, its probability of receiving non-standard audit opinions was apparently higher than others.

Secondly, there is a significant positive correlation between the information disclosure violations of listed companies and the audit fees of the current year and the next year. Furthermore,the audit fees of the violation companies are higher than other companies. Consequently, it can be concluded that information disclosure violations are more likely to increase audit fees.

\subsection{Countermeasures and Suggestions}

\subsubsection{Optimize the internal governance mechanism of the company}

First, improve the independent director system and the company's internal control system. Second, strengthen penalties for violations. Third, the independence of members in the audit committee should be guaranteed (Yun Lou, Feifei Wang, Tianxiang Yin,2017). 


\subsubsection{Strengthen the supervision responsibilities of intermediary agencies}

First of all, raising the difficulty of the applicants of auditing and educating their professional ethics continuously. Second, establish and improve the internal supervision system of intermediary institutions and open up channels for people to communicate with the supervision authorities.

\subsubsection{Strengthen the construction of industry ethics}

Carry out the moral education of securities market practitioners vigorously and hold the professional ethics education theme meetings for staff regularly.

This paper concludes that there is a significant positive correlation between information disclosure violations of listed companies and non-standard audit opinions and audit fees. The non-standard audit opinions issued by accounting firms and the continuous high audit fees might damage the confidence of investors of the listed company and force them to bear the financial burden, which is not conducive to the development of the company and the stability of the industry. Therefore, the improvement of the information revelation system of listed companies and the enforcement of the boundaries of information disclosure are in priority.

\section{Acknowledgments}

This paper was supported by: MOE (Ministry of Education in China) Project of Humanities and Social Sciences (Project No.15YJC630080)z; Sichuan University Students Innovation Training Program(Project No.201810636013); Sichuan Normal University 2019 "Training Programs of Innovation and Entrepreneurship for Undergraduates" (Project No.S201910636073).

\section{References}

[1] Duan Yuangang, Chen Bo. Loss of asset impairment, audit fees and audit opinions [J]. Audit research,2017(02): 40-47. (in Chinese)

[2] Li Tao, Wang Jianjun. Research on related party transaction fraud audit based on the theory of "two triangles of fraud" -- with Letv as an example [J]. Journal of finance and accounting, 2018(17):92-100. (in Chinese)

[3] Li Yun, Wang Feifei, Yin Tianxiang. CEO power, audit committee expertise and audit expenses [J]. Audit research, 2017(06): 91-98. (in Chinese)

[4] Xu Jianbin. Theoretical basis of accounting information disclosure of listed companies [J]. Chinese certified public accountant,2016(09):56-61. (in Chinese)

[5] Yuan George Shan, Indrit Troshani, (2016) "The effect of mandatory XBRL and IFRS adoption on audit fees: Evidence from the Shanghai Stock Exchange", International Journal of Managerial Finance, Vol. 12 Issue: 2, pp.109-135 